\title{
Quantitative and qualitative variables of semen from surubim do Iguaçu, Steindachneridion melanodermatum Garavello, 2005 (Siluriformes: Pimelodidae)
}

\author{
J. F. M. Sant'Anna ${ }^{a}$, A. Moraes-Neto ${ }^{b}$, J. P. Castro ${ }^{\text {, }, ~ T . ~ S . ~ S c z e p a n s k i ~}{ }^{a}$, J. A. Pohv ${ }^{b}$, \\ N. Lopera-Barrero ${ }^{d}$ and R. F. Artoni ${ }^{a, c *}$ \\ ${ }^{a}$ Programa de Pós-graduação em Biologia Evolutiva, Universidade Estadual de Ponta Grossa - UEPG, \\ Av. Carlos Cavalcanti, 4748, CEP 84030-900, Ponta Grossa, PR, Brasil \\ ${ }^{b}$ Programa de Pós-graduação em Ciência Animal, Universidade Federal de Mato Grosso do Sul - UFMS, \\ Av. Senador Felinto Müller, 2443, CEP 79070-900, Campo Grande, MS, Brasil \\ ${ }^{c}$ Programa de Pós-graduação em Genética Evolutiva e Biologia Molecular, Universidade Federal de São Carlos - UFSCar, \\ Rodovia Washington Luiz, Km 235, CEP 13560-970, São Carlos, SP, Brasil \\ ${ }^{d}$ Programa de Pós-graduação em Ciência Animal, Universidade Estadual de Londrina - UEL, \\ Rod. Cendo Garcia Cid, Pr 445, Km 380, CEP 86057-970, Londrina, PR, Brasil \\ *e-mail: rfartoni@gmail.com
}

Received June 23, 2016 - Accepted August 30, 2017 - Distributed February 28, 2019

(With 1 figure)

\begin{abstract}
The objective of the present work was to assess the qualitative and quantitative characteristics of semen from the surubim do Iguaçu (Steindachneridion melanodermatum). Induced spermiation was achieved in eleven males with mean weight of $1.76 \pm 0.48 \mathrm{~kg}$ and average age of two years and semen was collected by stripping. The average volume was $1.34 \pm 0.73 \mathrm{~mL}$. The duration of sperm motility was $154.4 \pm 72.6$ and $149.0 \pm 77.5$ seconds after activation with hatchery water and distilled water, respectively. The sperm concentration estimated by hemocytometer was $5.423 \pm 2.155 \times 10^{10}$ spermatozoa $/ \mathrm{mL}$. The results indicate that $S$. melanodermatum semen is easily obtained during the spawning season and the seminal characteristics are adequate insemination and subsequent in vitro fertilization.
\end{abstract}

Keywords: catfish, fish, Iguaçu river, reproduction, sperm quality, spermatozoa, Siluridae.

\section{Variáveis quantitativas e qualitativas de sêmen de Surubim do Iguaçu Steindachneridion melanodermatum Garavello, 2005 (Siluriformes: Pimelodidae)}

\section{Resumo}

O objetivo do presente trabalho foi avaliar características qualitativas e quantitativas do sêmen de surubim do Iguaçu (Steindachneridion melanodermatum). Para as análises, utilizaram-se onze machos com peso médio de 1,76 $\pm 0,48 \mathrm{~kg}$ e idade média de dois anos, submetidos ao tratamento de hipofisação. O volume médio de sêmen coletado foi de 1,34 $\pm 0,73 \mathrm{~mL}$. O tempo médio de motilidade dos espermatozoides após a coleta foi de 154,4 \pm 72,6 e 149,0 \pm 77,5 segundos para ativação com água do tanque e água destilada, respectivamente. Para a concentração espermática, a média foi de $5,423 \pm 2,155 \times 10^{10}$ espermatozoides $/ \mathrm{mL}$. Os resultados indicam que o sêmen de $S$. melanodermatum é facilmente obtido no período reprodutivo analisado, e que as características seminais avaliadas são adequadas para reprodução induzida.

Palavras-chave: bagre, peixe, rio Iguaçu, reprodução, qualidade espermática, espermatozoides, Siluridae.

\section{Introduction}

The Iguaçu river presents $1,320 \mathrm{~km}$ distance and is considered one of the most important tributaries of Paraná River basin (Bartozek et al., 2016). Regarding the fish species, such a river presents high degree of endemism which is estimated at $75 \%$ (Zawadzki et al., 1999). The ichthyofauna of Iguaçu river is also decreased when compared with

other rivers from the same basin (Júlio et al., 1997) and one of the most important fish are the siluriforms including the genera Steindachneridion. The Steindachneridion genus belongs to the Pimelodidae family, this genus is composed by catfishes which distribution is restricted to some hydrographic basins of South America. Regional 
endemism is a common characteristic of the genus. In a recent review, Garavello (2005) identified six species in this genus: S. scriptum and S. punctatum from the Paraná and Uruguay rivers, respectively; $S$. doceanum, from the Doce river; S. parahybae from the Paraíba rivers; $S$. amblyurum from the Jequitinhonha river; and $S$. melanodermatum from the Iguaçu river.

Similar to other Pimelodidae, S. melanodermatum, known as "surubim" or "monjolo" (Matoso et al., 2011), is interesting for aquaculture purposes since presents excellent meat quality, absence of intramuscular bones, good carcass yield, adaptation to captivity and good acceptance of artificial feeds. However, distribution of this species in the Iguaçu river basin is impacted with dams and other anthropic activities that led this species to the risk of extinction (Rosa and Lima, 2008). According to Agostinho et al. (2008), dam construction and the destruction of environments is one of the main causes of depletion of natural stocks.

One of the possible strategy to reduce the current threatening status is to increase the artificial propagation in aquaculture, and the Brazilian fish farming has shown great growth in recent years (IBGE, 2016; FAO, 2016). However, in order to improve such farming purposes it is necessary to improve the knowledge regarding the reproductive aspects for artificial reproduction and subsequent farming and restocking programs. In this context, studies with S. melanodermatum regarding its reproductive biology are then necessary. Ludwig et al. (2005) presented an adapted protocol for induced reproduction of $S$. melanodermatum. Marcos et al. (2015), report some reproductive characteristics for $S$. melanodermatum species, however, there are few studies of this catfish and its semen features.

Semen quality and other factors such as the water used for gamete activation are important to optimize in vitro fertilization. Studies evaluating the semen characteristics of South American fishes, such as Steindachneridion scripta (Luz et al., 2001), Leporinus elongatus (Streit Junior et al., 2008), Colossoma macropomum (Maria et al., 2012), Brycon orbignyanus (Galo et al., 2011), Pseudoplatystoma reticulatum (Streit Junior et al., 2012), Leiarius marmoratus (Galo et al., 2014) and S. melanodermatum (Marcos et al., 2015) have been conducted in recent years to determinate the actual potential of each species in fish farming activities.

The present study aimed to evaluate the qualitative and quantitative sperm characteristics of $S$. melanodermatum in order to contribute towards its biological conservation and use in commercial purposes.

\section{Material and Methods}

The study was conducted in January during the spawning season of 2006. at the Ichthyologic Experimental Station of the Ney Braga Hydroelectric Plant, from Paraná Electric Company and located at the Candói dam in Paraná State, Brazil. The fish were sampled with permission Instituto Brasileiro do Meio Ambiente e dos Recursos Naturais Renováveis (IBAMA/MMA proc. $\mathrm{n}^{\circ}$ 02017.000686/00-21), from the stock of surubim do Iguaçu established since 1998 in the Experimental Station of Ichthyological Studies of the Energy Company of Paraná (COPEL). All the procedures followed the international standards of animal research ethics. Eleven specimens of $S$. melanodermatum were selected, with average weight of $1.76 \pm 0.48 \mathrm{~kg}$ and mean age of two years, from the Iguaçu river (Salto Caxias). The criteria for selection of broodstock were volume and flaccidity adbomen and hyperemic urogenital papilla in female, while semen fluidity in males. The fishes remained in the tanks at the station for induced reproduction using the method described by Ludwig et al. (2005) and restocking in the same hydrographic basin.

The procedures for induced spawning in this study followed the previous protocols for native species proposed by Zaniboni-Filho and Barbosa (1996) and adapted for S. melanodermatum by Ludwig et al. (2005). The breeders were transferred to laboratory tanks with artificial aeration and constant water renovation. Then, the fish were weighed and induced to spawn with an intramuscular injection containing $0.25 \mathrm{mg} \mathrm{CPE} / \mathrm{kg}$ and subsequently after 24 hours another dose of $2.5 \mathrm{mg}$ of carp pituitary extract (CPE) $/ \mathrm{kg}$.

After 180 hourgrades, the males were anesthetized, the urogenital papilla was dried and the sperm was sampled by stripping in $15-\mathrm{mL}$ tubes and then maintained in an ice box $\left(\sim 4^{\circ} \mathrm{C}\right)$. The seminal volume was determined using a $100 \mu \mathrm{M}$ micropipettes (HTL, Poland, Warsaw). The duration of sperm motility was performed using two activating solutions, hatchery water and distilled water. The semen was activated by a 2 -fold dilution and observed on a microscope Nikon Eclipse E-200, Japan, Hokkaido under (1.000x magnification). Motility duration (in seconds) was defined when sperm stopped motility. This procedure was performed five times for each sample, following the procedure described by Luz et al. (2001). For motility analysis was bassed on the procedure described by Iwamatsu et al. (1993) with some modifications. The sperm movement was observed given in the phase contrast microscope with 40x magnification (Nikon Eclipse E-200, Japan, Hokkaido).

To determine sperm concentration, semen was diluted in a buffered saline- formaldehyde solution (CBRA 2013) after a 7000-fold dilution and counts were performed in a Neubauer hemocytometer chamber (Laboroptik, Lancing, United Kingdom).

The morphology was also determined by the procedures described by Kavamoto et al. (1999) with modifications. The sperm was diluted 2 -fold with a $10 \%$ malachite green solution. After $2 \mathrm{~min}$, the sperm was pipetted on a microscope slide and prepared a smear. The slide was then rinsed with running water and dried at room temperature for one hour and subsequenty stained by fuchsin or malachite green. Each slide was the observed at the microscope (Nikon Eclipse E-200, Japan, Hokkaido) at 1000x magnification.

\section{Results and Discussion}

The present study demonstrated that during the spawning season, S. melanodermatum males released the sperm after hormonal treatment by stripping. Specimens maintained in captivity with adequate feed and water provide good 
results (Table 1). Marcos et al. (2015), observed for this species in October higher volumes (mean of $11.7 \mathrm{~mL}$ ) when compared with the present experiment. Such a difference may arise because January those fish may be at the end of the spawning season, as observed in other Neotropical species which concentrates the reproduction during the October to December (Godoy, 1975; Vazzoler, 1996; Agostinho et al., 2004).

In natural populations, qualitative and quantitative aspects of the semen are lower at the end of reproductive cycle since. Although the fish in the present study are domesticated, we observed a similar trend. According to Godinho et al. (2003), the volume of sperm produced by fishes is variable and depends on the size of the individual, season and sampling method. The volume of semen from the S. melanodermatum was also lower than that described by Luz et al. (2001) for S. scriptum (4-20 mL/male). However, similar values were obtained by Araújo et al. (2014) for Leiarius marmoratus (1.3-1.7 mL/male). This information suggests that this parameter is species specific and also period-dependent.

The analysis of motility duration of $S$. melanodermatum revealed similar results with activation using tank water (154.4 \pm 72.6 seconds) and distilled water ( $149.0 \pm 77.5$ seconds) (Table 1). These values were higher than those obtained by Marcos et al. (2015) for S. melanodermatum, which found an average of 79.31 seconds, most probably due to the higher dilution we used in the present study.

Motility duration (Table 1) were higher than those observed by Luz et al. (2001) for S. scriptum from the Uruguay River basin, which ranged from 46 to 75 seconds. Araújo et al. (2014), also report lower motility time (86.0 to 95.8 seconds) for Colossoma macropomum (Characiformes: Characidae). The increased motility duration may improve fertilization success, as the motile spermatozoa have longer period to fertilize the oocytes. Thus, the motility activation used in this study gave rise to an increased motility duration, which may improve the fertilization ability during in vitro fertilization. This fact is interesting since Weingartner and Zaniboni-Filho (2013) suggested that the low fertilization rate of Salminus brasiliensis may be related to the short duration of sperm motility ( 35 seconds).

The mean concentration of spermatozoa of S. melanodermatum was $5.423 \pm 2.155 \times 10^{10}$ spermatozoa $/ \mathrm{mL}$ (Table 1). Marcos et al. (2015), observed lower sperm concentration (1.03 x $10^{10}$ spermatozoids $/ \mathrm{mL}$ ) for this species, possibly due to the higher volume of semen obtained by these authors. Luz et al. (2001) describe concentrations between 1.95 and $12.015 \times 10^{10}$ spermatozoa $/ \mathrm{mL}$ for S. scriptum. Maria et al. (2012) describe concentration of $0.79 \times 10^{10}$ spermatozoa/mL for Colossoma macropomum, while Araújo et al. (2014) for the same species found $0.313 \times 10^{10}$ spermatozoa $/ \mathrm{mL}$. These data demonstrate the considerable variation in sperm concentration both between and within species. It is evident that $S$. melanodermatum has a higher sperm concentration when compared with related species.

In the present study, malachite green was used for the visualization of the sperm cells and showed satisfactory staining and morphology (Figure 1), when compared with fuchsin, which is often employed for similar analysis. This method becomes then interesting in order to determine the morphological pattern as well as sperm abnormalities in $S$. melanodermatum. In addition, this dye may be potentially applicable for other teleosts and this fact is attractive since these parameters are related with fertilization ability. The results of the present study demonstrate that the semen of S. melanodermatum is easily obtained in the breeding season, and that the evaluated characteristics are adequate for induced reproduction of this species. However, the results observed in Marcos et al. (2015) indicate that possibly the breeders used in the present experiment were not in the peak of the spawning season. Other reproductive aspects of this species including motility analysis by the Computer Assisted Sperm Motility Analysis (CASA) (Kime et al., 2001) and establish a correlation with fertilization, and the evaluation of the gamete quality during all the reproduction period is then an interesting strategy to improve reproduction for both conservation and aquaculture.

Table 1. Qualitative and quantitative characteristics of semen from S. melanodermatum.

\begin{tabular}{|c|c|c|c|c|c|c|}
\hline \multirow[t]{2}{*}{ Specimen } & \multirow{2}{*}{$\begin{array}{c}\text { Weight } \\
\text { (kg) }\end{array}$} & \multirow[t]{2}{*}{ Aspect } & \multirow{2}{*}{$\begin{array}{l}\text { Vol. } \\
(\mathrm{mL})\end{array}$} & \multicolumn{2}{|c|}{$\begin{array}{c}\text { Motility time } \\
\text { (seconds) }\end{array}$} & \multirow{2}{*}{$\begin{array}{l}\text { Concentration } \\
\left(\times 10^{10} \text { cell } / \mathrm{mL}\right)\end{array}$} \\
\hline & & & & Tank water & Distilled water & \\
\hline 1 & 1.8 & Dense & 0.8 & - & - & 7.45 \\
\hline 2 & 1.3 & Semi-dense & 1.2 & 143 & 136 & 2.80 \\
\hline 3 & 1.1 & Semi-dense & 2.3 & 85 & 66 & 3.47 \\
\hline 4 & 2.3 & Semi-dense & 0.6 & 175 & 142 & 3.15 \\
\hline 5 & 1.2 & Semi-dense & 1.0 & 132 & 121 & 3.97 \\
\hline 6 & 1.4 & Dense & 0.8 & 211 & 182 & 7.55 \\
\hline 7 & 1.7 & Semi-dense & 1.4 & 129 & 127 & 5.42 \\
\hline 8 & 2.3 & Semi-dense & 2.5 & 186 & 167 & 4.45 \\
\hline 9 & 1.7 & Dense & 2.3 & 292 & 268 & 8.02 \\
\hline 10 & 2.2 & Aqueous & 1.4 & 22 & 18 & 8.80 \\
\hline 11 & 2.4 & Semi-dense & 0.4 & 169 & 163 & 4.57 \\
\hline Mean & $1.76 \pm 0.48$ & - & $1.34 \pm 0.73$ & $15.44 \pm 7.26$ & $14.90 \pm 7.75$ & $5.423 \pm 2.155$ \\
\hline
\end{tabular}




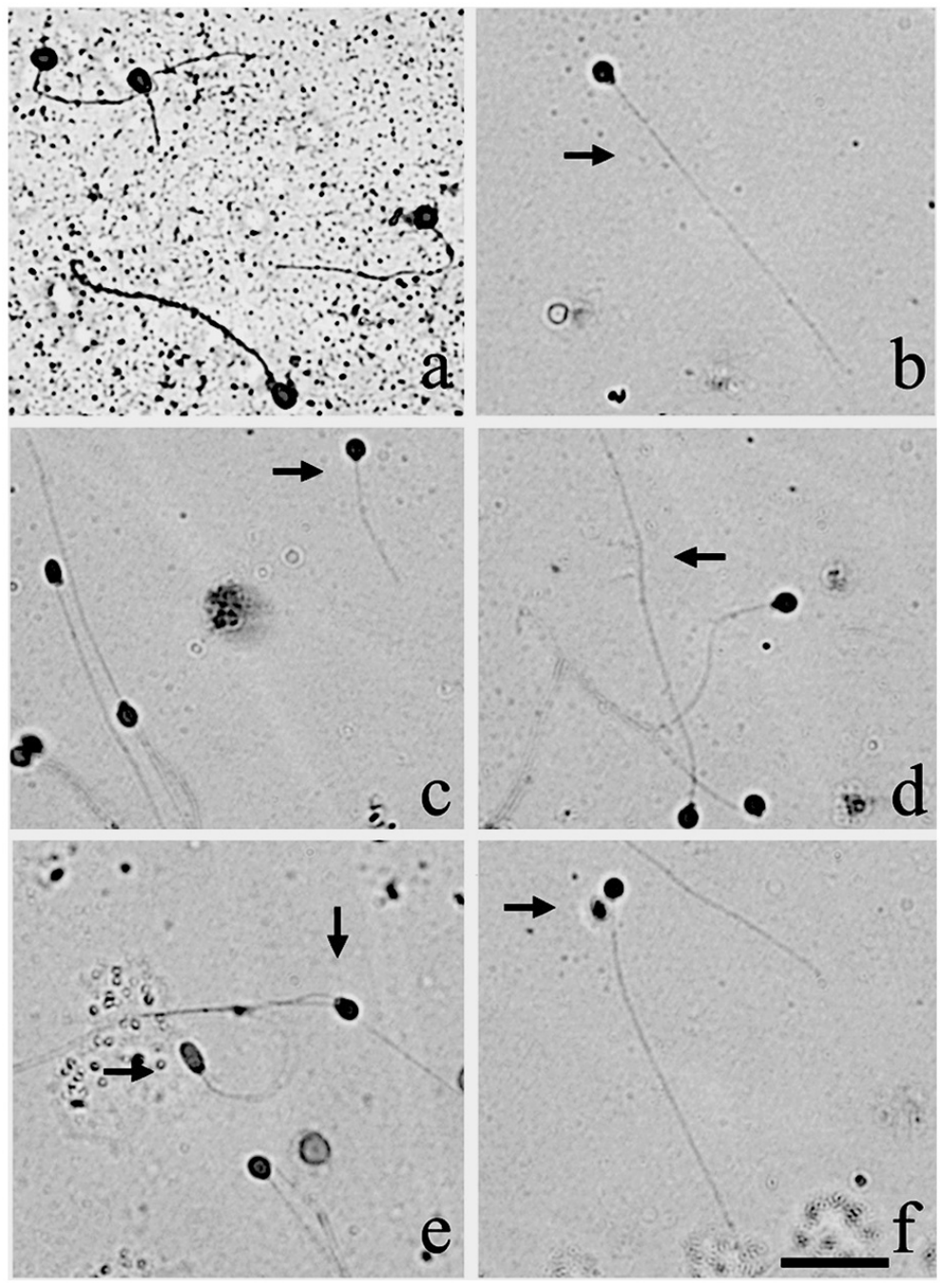

Figure 1. Photomicrograph of $S$. melanodermatum sperm visualized under brightfield microscopy using a 1,000x magnification. The sperm was stained with acid fuchsin (a) and malachite green (b), (c), (d) and (f). Arrows indicate sperm morphological types verified (b), short flagellum (c), long flagellum (d), double oval head and flagellum (e) and small head and the absence of midpiece (f). Bar $=50 \mu \mathrm{m}$.

\section{Acknowledgements}

The authors are grateful to Dr. Claudinei Cruz and Dra. Verônica O. Vianna for the critiques of the manuscript, and to biologist Luis A. M. Ludwig for enabling the assays at the Ichthyologic Experimental Station of the Ney Braga Hydroelectric Plant (COPEL). This study was supported by Fundação Araucária para o Desenvolvimento Científico e Tecnológico do Estado do Paraná.

\section{References}

AGOSTINHO, A.A., GOMES, L.C., VERÍSSIMO, S.K. and OKADA, E.K., 2004. Flood regime, dam regulation and fish in the Upper Parana River: effects on assemblage attributes, reproduction and recruitment. Reviews in Fish Biology and Fisheries, vol. 14, no. 1, pp. 11-19. http://dx.doi.org/10.1007/s11160-004-3551-y.
AGOSTINHO, A.A., PELICICE, F. and GOMES, L.C., 2008. Dams and the fish fauna of the Neotropical region: impacts and management related to diversity and fisheries. Brazilian Journal of Biology $=$ Revista Brasileira de Biologia, vol. 68, no. 4, suppl., pp. 1119-1132. http://dx.doi.org/10.1590/S151969842008000500019. PMid:19197482.

ARAÚJO, J.Ê.X.S., STREIT JR., D.P., RIBEIRO, J.S.A., MARTINS, E.F.F., SOUZA, F.N., OLIVEIRA, C.A.L., RIBEIRO, R.P., LOPERA-BARRERO, N.M. and POVH, J.A., 2014. Ovopel and carp pituitary extract as spawning inducers in males of the Amazon Catfish Leiarius marmoratus (Gill, 1970). Brazilian Archives of Biology and Technology, vol. 57, no. 6, pp. 882-886. http://dx.doi.org/10.1590/S1516-8913201402469.

BARTOZEK, E.C.R., BUENO, N.C., FEIDEN, A. and RODRIGUES, L.C., 2016. Response of phytoplankton to an experimental fish culture in net cages in a subtropical reservoir. Brazilian Journal of Biology $=$ Revista Brasileira de Biologia, 
vol. 76, no. 4, pp. 824-833. http://dx.doi.org/10.1590/15196984.00115. PMid:27166569.

COLÉGIO BRASILEIRO DE REPRODUÇÃO ANIMAL CBRA, 2013. Manual para exame andrológico e avaliação de sêmen animal, 3rd ed. Belo Horizonte: Colégio Brasileiro de Reprodução Animal.

FOOD AND AGRICULTURE ORGANIZATION OF THE UNITED NATIONS - FAO, 2016. The state of world fisheries and aquaculture: contributing to food security and nutrition for all. Rome: FAO.

GALO, J.M., STREIT JR., D., POVH, J., FORNARI, D.C., RESENDE, E.K., OLIVEIRA, D. and RIBEIRO, R.P., 2014. Sperm quality of the Amazon catfish Leiarius marmoratus (Gill, 1870) after cold storage. Brazilian Journal of Biology $=$ Revista Brasileira de Biologia, vol. 74, no. 4, pp. 933-938. http://dx.doi. org/10.1590/1519-6984.00313. PMid:25627605.

GALO, J.M., STREIT JR., D., SIROL, R., RIBEIRO, R.P., DIGMAYER, M., ANDRADE, V.X. and EBERT, A.R., 2011. Spermatic abnormalities of piracanjuba Brycon orbignyanus (Valenciennes, 1849) after cryopreservation. Brazilian Journal of Biology $=$ Revista Brasileira de Biologia, vol. 71, no. 3, pp. 693-699. http://dx.doi.org/10.1590/S1519-69842011000400014. PMid:21881793.

GARAVELLO, J.C., 2005. Revision of genus Steindachneridion (Siluriformes: Pimelodidae). Neotropical Ichthyology, vol. 3, no. 4, pp. 607-623. http://dx.doi.org/10.1590/S1679-62252005000400018.

GODINHO, H.P., AMORIM, V.M.C. and PEIXOTO, M.T.D. (2003). Criopreservação do sêmen de tilápia- nilótica oreochromis niloticus, var. chitralada: Crioprotetores, soluções ativadoras e refrigerador criogênico. Revista Brasileira de Zootecnia, vol. 32, no. 6, suppl 1, pp. 1537-1543. http://dx.doi.org/10.1590/ S1516-35982003000700001.

GODOY, M.P. (1975). Peixes do Brasil subordem Characoidei. Bacia do rio Mogi Guassu. Braga: Editora Franciscana.

INSTITUTO BRASILEIRO DE GEOGRAFIA E ESTATÍSTICA - IBGE. Sistema IBGE de Recuperação Automática - SIDRA, 2016 [viewed 15 December 2016]. Pesquisa da Agropecuária Municipal [online]. Available from: https://sidra.ibge.gov.br/ Tabela/3940

IWAMATSU, T., ISHIJIMA, S. and NAKASHIMA, S., 1993. Movement of spermatozoa and changes in micropyles during fertilization in medaka eggs. The Journal of Experimental Zoology, vol. 266, no. 1, pp. 57-64. http://dx.doi.org/10.1002/ jez.1402660109.

JÚLIO, J.R., BONECKER, C.C. and AGOSTINHO, A.A., 1997. Reservatório de Segredo e sua inserção na bacia do rio Iguaçu. In: A.A. AGOSTINHO and L.C. GOMES, eds. Reservatório de Segredo: bases ecológicas para o manejo. Maringá: EDUEM, pp. 1-17.

KAVAMOTO, E.T., BARNABE VH, CAMPOS, B.E.S. and TALMELLI, E.F.A., 1999. Anormalidades morfológicas nos espermatozóides do curimbatá, Prochilodus lineatus (Steindachner, 1881) (Osteichthyes, Characiformes, Prochilodontidae). Boletim do Instituto de Pesca, vol. 25, pp. 61-66.

KIME, D.E., VAN LOOK, K.J., MCALLISTER, B.G., HUYSKENS, G., RURANGWA, E. and OLLEVIER, F., 2001. Computer-assisted sperm analysis (CASA) as a tool for monitoring sperm quality in fish. Comparative Biochemistry and Physiology. Toxicology \& Pharmacology : CBP, vol. 130, no. 4, pp. 425-433. http://dx.doi.org/10.1016/S1532-0456(01)00270-8. PMid:11738630.

LUDWIG, L.A.M., GOMES, E. and ARTONI, R.F., 2005. Um método de reprodução induzida para O Surubim Steindachneridion Melanodermatum (Siluriformes, Pimelodidae) do Rio Iguaçu. Ciências Biológicas e da Saúde, vol. 11, pp. 23-27. http://dx.doi. org/10.5212/publicatio\%20uepg.v11i3.417.

LUZ, R.K., FERREIRA, A.A., REYNALTE, D.A.T. and ZANIBONI FILHO, E., 2001. Avaliação ualitativa e quantitativa do sêmen de Suruvi, Steindachneridion scripta (Pimelodidae). Boletim do Instituto de Pesca, vol. 27, no. 1, pp. 39-42.

MARCOS, R.M., NEUMANN, G., TOLEDO, C.P.R., SENA, J.M., BAUMGARTNER, G. and BOMBARDELLI, R.A., 2015. Seminal and spermatic characteristics of fresh semen and the effects of sperm cooling in Steindachneridion melanodermatum (Garavello, 2005). Semina: Ciências Agrárias, vol. 36, no. 6, suppl. 2, p. 4493. http://dx.doi.org/10.5433/1679-0359.2015v36n6Sup12p4493.

MARIA, A.N., AZEVEDO, H.C., SANTOS, J.P. and CARNEIRO, P.C.F., 2012. Hormonal induction and semen characteristics of tambaqui Colossoma macropomum. Zygote, vol. 20, no. 1, pp. 39-43. http://dx.doi.org/10.1017/S0967199410000559. PMid:21208496.

MATOSO, D.A., ALMEIDA VAL, V.M.F., SILVA, M., MORAES-NETO, A., ALMEIDA, M.C., VICARI, M.R., MOREIRA-FILHO, O. and ARTONI, R.F., 2011. Chromosomal polymorphism in Steindachneridion melanodermatum Garavello, 2005 (Siluriformes, Pimelodidae): a reappraisal the existence of sex chromosome system in the species. Reviews in Fish Biology and Fisheries, vol. 21, no. 3, pp. 497-508. http://dx.doi.org/10.1007/ s11160-011-9201-2.

ROSA, R.D.S. and LIMA, F.C.T., 2008. Os peixes brasileiros ameaçados de extinção. In: A.B. MACHADO, G.M. DRUMOND and A.P. PAGLIA, eds. O livro vermelho da fauna brasileira ameaçada de extinção. Brasília: Ministério do Meio Ambiente, pp. 9-275.

STREIT JUNIOR., D.P., SIROL, R.N., RIBEIRO, R.P., MORAES, G.V., VARGAS, L.D. and WATANABE, A.L., 2008. Qualitative parameters of the piapara semen (Leporinus elongatus Valenciennes, 1850). Brazilian Journal of Biology = Revista Brasileira de Biologia, vol. 68, no. 2, pp. 373-377. http://dx.doi.org/10.1590/ S1519-69842008000200019. PMid:18660966.

STREIT JUNIOR, D.P., SIROL, R.N., RIBEIRO, R.P., MORAES, G.V., VARGAS, L.D.M. and WATANABE, A.L., 2012. Parâmetros seminais de reprodutores de Pseudoplatystoma reticulatum, em cativeiro, pré e pós-indução hormonal. Revista Brasileira de Reprodução Animal, vol. 36, pp. 188-193.

VAZZOLER, A.E.A.M., 1996. Biologia da reprodução de peixes teleósteos: teoria e prática. Maringá: EDUEM.

WEINGARTNER, M. and ZANIBONI-FILHO, E., 2013. Dourado. In: B. BALDISSEROTTO and L.C. GOMES, eds. Espécies nativas para a piscicultura no Brasil. Santa Maria: Editora UFSM, pp. 257-286.

ZANIBONI-FILHO, E. and BARBOSA, N.D.C., 1996. Priming hormone administration to induce spawning of some Brazilian migratory fish. Revista Brasileira de Biologia, vol. 56, pp. 655-659.

ZAWADZKI, C.H., RENESTO, E. and BINI, L.M., 1999. Genetic and morphometric analysis of three species of the genus Hypostomus Lacepede, 1803 (Osteichthyes : Loricariidae) from the Rio Iguacu basin (Brazil). Revue Suisse de Zoologie, vol. 106, pp. 91-105. http://dx.doi.org/10.5962/bhl.part.80072. 